UDC 574: 504.064.37:502.51-044.3(477)=111

DOI https://doi.org/10.32846/2306-9716-2019-1-24-1-16

\title{
EVALUATION OF EUTROPHICATION THE DNIEPER RIVER IN THE CITY OF KYIV WITH USE MEANS ARCGIS 10.4.1 AND LANDSAT 8
}

\author{
Lapyga I.V. \\ M.P. Dragomanov National Pedagogical University \\ 9, Pirogov Str., 01601, Kyiv \\ espritfort@yahoo.com
}

The research results of spatial-temporal eutrophication the Dnieper River coastal areas within of the Kiev city during 2017-2018 whit using the fluorescence methods, facilities of satellite channel Landsat 8 and the applied computer program ArcGis 10.4.1 are presented. The flowering maximum intensity of the water surface in August was revealed, which is typical mainly for the places of water discharge from industrial enterprises. Water surface bloom maximum intensity in August was revealed, which is typical mainly for the places of water discharge from industrial enterprises. Obtained data using, chlorophyll- $a$ concentration from the satellite channel Landsat 8 showed a high correlation of $0,87(\mathrm{p} \leq 0,05)$ with the data measured by the fluorometric method, which indicates prospectively of the satellite channel use for accuracy evaluation improve of the trophical condition Dnieper's and other rivers of Ukraine, especially in areas that are difficult to reach or where military operations take place. Key words: eutrophication, trophic state in rivers, chlorophyll, Landsat 8, multispectral images, ArcGis.

Оцінювання евтрофікації річки Дніпро в межах міста Києва із застосуванням засобів ArcGis 10.4.1 тa Landsat 8. Лапига I.В. Наведено результати дослідження просторово-часової евтрофікації прибережних ділянок річки Дніпро в межах міста Києва впродовж 2017-2018 років із застосуванням методів флуорометрії, засобів супутникового каналу Landsat 8 та прикладної комп'ютерної програми ArcGis 10.4.1. Виявлено максимальну інтенсивність цвітіння водної поверхні в серпні, характерну переважно для місць надходження стічних вод із промислових підприємств. Використання отриманих даних концентрації хлорофілу- $a$ із супутникового каналу Landsat 8 показало високу їх кореляцію $(0,87(\mathrm{p} \leq 0,05))$ з даними, що виміряні методом флуорометрії, що вказує на перспективність використання засобів супутникового каналу для підвищення точності оцінювання трофічного стану Дніпра та інших річок в Україні, особливо у важкодоступних районах або там, де здійснюються бойові дії. Ключові слова: евтрофікація, трофічний стан річки, хлорофіл, Landsat 8, мультиспектральні зображення, ArcGis.

Оценивание эвтрофикации реки Днепр в пределах города Киева с применением средств ArcGis 10.4.1 и Landsat 8. Лапыга И.В. Приведены результаты исследования пространственно-временной эвтрофикации прибрежных территорий реки Днепр в пределах города Киева на протяжении 2017-2018 годов с применением методов флуоресценции, средств спутникового канала Landsat 8 и прикладной компьютерной программы ArcGis 10.4.1. Выявлена максимальная интенсивность цветения водной поверхности в августе, характерная в основном для мест поступления сточных вод с промышленных предприятий. Использование полученных данных концентрации хлорофилла-а со спутникового канала Landsat 8 показало высокую их корреляцию $(0,87$ ( $\leq \leq 0,05))$ с данными, измеренными методом флуорометрии, что указывает на перспективность использования средств спутникового канала для повышения точности оценивания трофического состояния Днепра и других рек Украины, особенно в тяжело доступных районах либо там, где осуществляются боевые действия. Ключевые слова: эвтрофикация, трофическое состояние реки, хлорофилл, Landsat 8, мультиспектральные изображения, ArcGis.

Problem statement. Eutrophication is one of the pressing environmental problems that covers lakes, rivers and seas around the world and is accompanied by flowering and deterioration water quality [1]. The results of numerous studies provided grounds to believe that this is due to an increase in the amount of blue-green algae due to an increase the amount of phosphorus, nitrogen and other pollutants with which wastewater is enriched, especially near large industrial cities and agricultural lands [2]. This problem is also current for the Dnieper River.
Currently, in the many of environmental projects aimed at studying and solving the problem of river eutrophication, traditional methods of mathematical modeling are used: the nutrient load model [3], the ecological model of phytoplankton $[4 ; 5]$, the dynamic model [6-8] and others.

The construction of such models is carried out on the data obtained basis by direct sampling of water at specialized observation stations and at other selected places (points) of river. The impossibility of simultane- 
ous measurement of the studied indicators of the entire points set on a large area of the river leads to the problem of the accuracy of monitoring, further calculations, generalizations and, accordingly, decision making. The use of efficient satellite and computer automation tools for assessing the ecological status of water resources, along with traditional methods of environmental monitoring, will help improve the accuracy of monitoring and the implementation of priority areas of environmental management activities of the Ukraine Government, in particular, improving the ecological status of the Dnieper River, which share about $80 \%$ [9].

Research relevance is the need in introduce automated methods to improve the evaluation accuracy of the condition and spatial-temporal tendency eutrophication of the Dnieper coastal areas within the city of Kyiv, that will contribute to the realization of tasks the International program of Global Climate Observing System (GCOS), in particular, of the implementation activities of automation methods and improving the water condition resources assessment accuracy.

Relation of author's rework with important scientific and practical tasks. The study results, disclosed in the article, reflect the current trend in the Dnieper River eutrophication, as well as expanding representation of possibilities of using satellite and computer automation tools to improve the accuracy of estimating the trophic state and to study other rivers. The complexly use traditional method fluorescence and modern satellite facilities with computer software Arc GIS 10.4.1 contributes not only to solving the accuracy of the trophic state assessment of the rivers studied, but also to implement the state concept of the national ecological Ukraine policy for the period up to 2020. In particular, this can contribute to improving the efficiency of environmental activities, which includes not only the implementation of relevant event, but also the use of effective methods for automating the assessment of the water resources ecological status of rivers.

Analysis of recent research and publications. Analysis of the recent studies results and publications showed, that increasing the intensity of eutrophication water bodies is a global problem. The need to improve the water resources quality is emphasized in many scientific papers [10; 11], in particular Clarc at. al. [12] brings examples of the documented deterioration of water quality in water bodies on every continent such as the Baltic Sea in Europe [13], Lake Victoria in Africa [14], Lake Taihu in Asia [15], Lake Erie in North America [16], Murray River in Australia [17], several reservoirs in South America [18], and even Antarctica [19]. This problem is also current for the Dnieper river reservoirs [20]. The solution of this problem largely depends on the measured data accuracy, therefore, to improve for accuracy of predicting the chlorophyll $a(\mathrm{Chl}-a)$ in water concentration, it is offered mandatory to build models [21] based on the integrated use a not only of laboratory data, but also satellite data. Such an approach will contribute to solving the tasks of the Global Climate Observing System, in particular, unlocking the using potential of satellite facilities to improve for monitoring water resources accuracy [22].

Highlight of the earlier unresolved parts of the general problem, to which the article is devoted. One from urgent problems Dnieper River ecological status of the within Kyiv is the deterioration of water quality due to an increase in the number of blue-green algae. The solution to this problem, usually, provides for mandatory monitoring of the chlorophyll concentration in water. When using only traditional fluorometry method with direct water sampling in separate selected river points, the problem of the measured data accuracy and distribution of this sample values to entire river points set remains unresolved, which reduces the evaluations' accuracy trophic state of the river accordingly.

Based from above, the purpose of this work was to identify the trend of spatio-temporal eutrophication of the Dnieper River coastal sections within of the city Kyiv using the fluorometry traditional method, as well as the satellite channel Landsat 8 and the application program ArcGis 10.4.1.

Researches originality lies in the integrated application methods of fluorometry, computerized facilities of ArcGis 10.4.1 and the satellite channel Landsat 8 to improve the evaluation accuracy of the condition and spatial-temporal tendency of the Dnieper river eutrophication within of the city Kyiv, with order of assistances the strategies development for the restoration of water resources in conditions of increasing anthropogenic load.

Methodological or general scientific value. The methodological or general scientific value consists in disclosing the advantages of the simultaneous integrated use of satellite channel Landsat 8 facilities, geographic information systems and the traditional of fluorimeter method for evaluating the Dnieper River eutrophication within of the city Kyiv. The active use of traditional and modern satellite channel facilities and ArcGIS tools will contribute to improving the environmental monitoring system, improving the accuracy of assessing the trophic condition of river water resources in industrial cities, as well as integrating EU environmental requirements into the state environmental policy of Ukraine.

Materials and methods. In the within city of Kiev, during April - October 2016-2017, the eutrophication of the Dnieper river was investigated from indicator of the biomass of blue-green and green algae in the surface layer of the aquatic environment. Quantitative values of the algae biomass were determined by two methods from the concentration of Chl- $a$ in water. In the first method, as in our other experiments [23; 24], a "SpectroVis Plus" fluorometer (Vernier, USA) was used with such a sequence of actions. Water samples were taken at arbitrarily selected points (with GPS coordinates fixation) at a distance of $0,5-5,0 \mathrm{~m}$ from the coast and filtered with a vacuum pump in a vacuum of $45 \mathrm{GPa}$. 
With the target of prevent Chl- $a$ destruction, before filtering of solution, the filters were treated with a suspension of $\mathrm{MgCO}_{3}$, prepared by adding $1 \mathrm{~g}$ of milled $\mathrm{MgCO}_{3}$ to $100 \mathrm{ml}$ of distilled water. To extract the pigments, the filter with the precipitate was placed in a glass test tube, filled with $90 \%$ acetone solution to a volume of $10 \mathrm{ml}$ and kept for 10-15 minutes in the dark at a temperature of $+21^{\circ} \mathrm{C}$. Thereafter, the extract was centrifuged for 10 minutes at $4000 \mathrm{rpm}$. The resulting clear extract was poured into fluorometry cuvettes. The optical density of the chlorophyll extract and control solution (90\% acetone) in the cuvettes was measured with a fluorometer at wavelengths of 430, 664, 647, $630 \mathrm{~nm}$ [25]. Based on the optical density measured values of extract, the Chl- $a$ concentration was calculated by the formula [26]:

$$
\begin{gathered}
\text { Chl }-a=11.85(\mathrm{OD} 664)-1.54(\mathrm{OD} 647)- \\
0.08(\mathrm{OD} 630) .
\end{gathered}
$$

In the second method, with tools of "Landsat 8" satellite channel United State Geological Survey (USGS) obtained multispectral cartographic digitized images of the studied river sites. From the aggregate of the obtained graphic files only formats were used, in which the pixels' color hues are capable of displaying the Chl- $a$ concentration at each point studied. These are files with the spectra "Green (B3)" and "NIR (B5)", based on which, using a tool "Raster Calculator" in program
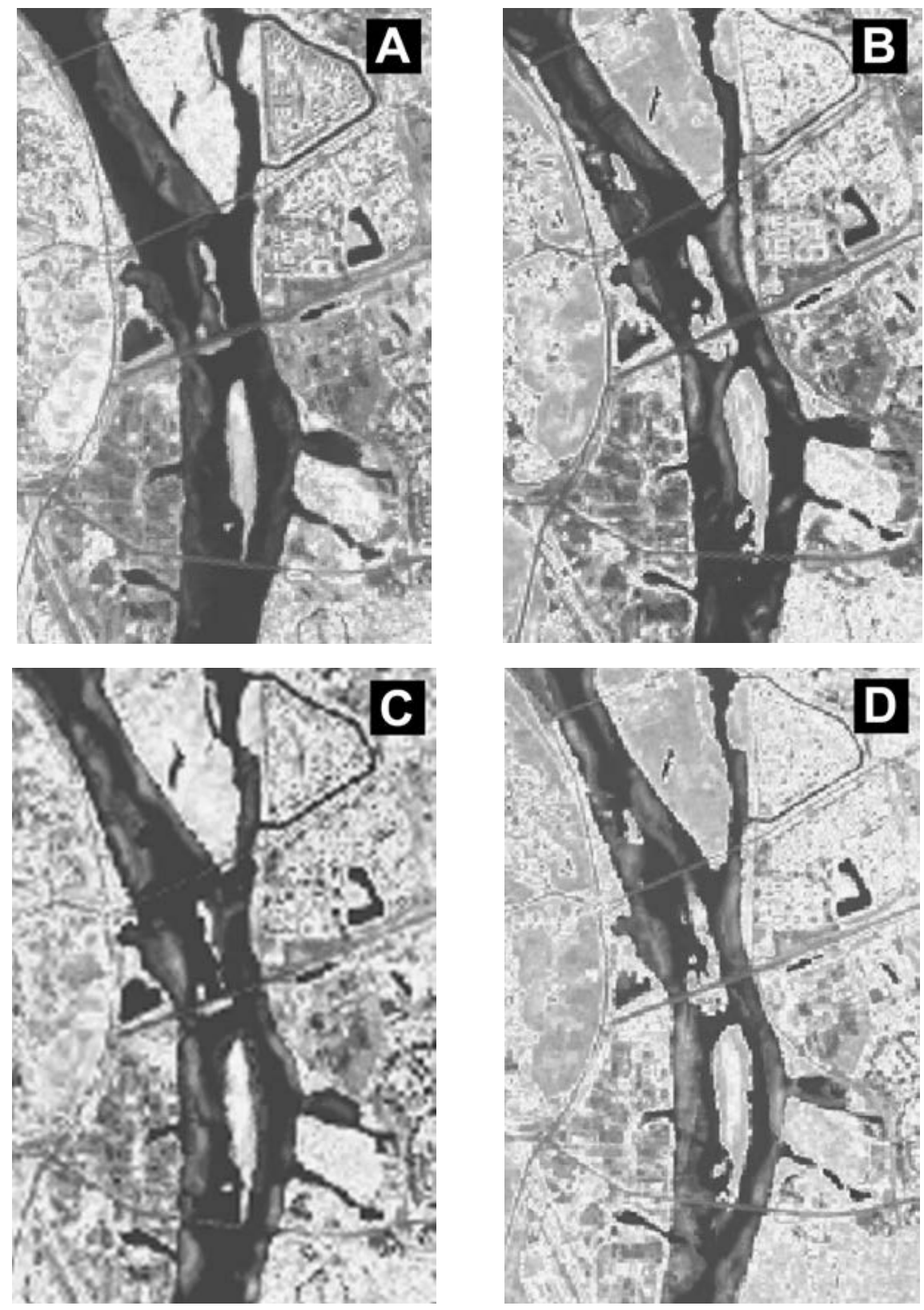

Fig. 1. Changes in TSI Chl-a on the surface of the Dnieper River within the city of Kyiv: A, B - in April, August (2017) C, D-in April, August (2018) (used thermographic images from Landsat 8 satellite channel, USGS) 
ArcGIS 10.4.1 was calculated for each pixel the values Normalized Difference Water Index (NDWI) [27]:

$$
\text { NDWI }=(\text { Green }- \text { NIR }) /(\text { Green }+ \text { NIR }) .
$$

The pixel index NDWI values calculated of the were stored for subsequent analysis in tabular form in an electronic database.

Based on the data, obtained by the two methods mentioned above, the type of Dnieper river trophic state within the city of Kyiv was determined. Eutrophication was assessed with using threshold values, which was determined for trophical states index (TSI) by Carlson for water objects. For this used the formula [28]:

TSI Chl- $a=10(6-((2,04-(0,68 \ln ($ Chl- $a)) / \lg 2))$,

compared them with the TSI scale [28]. On this scale, the trophic condition was considered oligotrophic, with concentration $<2 \mu \mathrm{g} / \mathrm{L}$, mesotrophic from 2 to $7 \mu \mathrm{g} / \mathrm{L}$, eutrophic from 7 to $30 \mu \mathrm{g} / \mathrm{L}$, hypertrotrophic at $>30 \mu \mathrm{g} / \mathrm{L}$.

The pigment index (PI) calculated by the formula [25]:

$$
\text { PI }=\text { OD } 430 \text { / OD } 664 .
$$

Statistical indicators were processed using Statistica 12.0.

Statement of the main material. The indicator role of phytoplankton is determined not only by the presence or absence of certain species in the reservoir, but
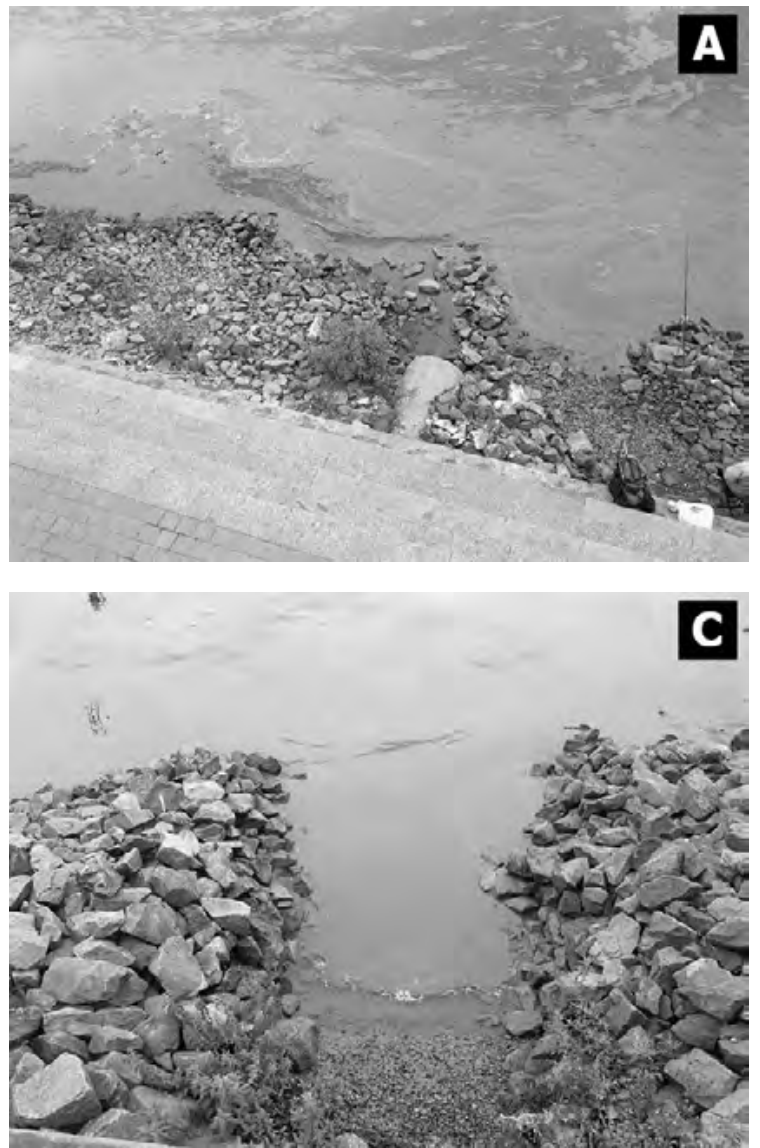

also by the indicators of their quantitative development. The identification of phytoplankton quantitative indicators allows us to predict its development and possible tendency trophic state of water body. Among the methods of obtaining quantitative phytoplankton indicators, the greatest interest determination volume of pigments in him. The main for quantitative content in phytoplankton cells and the most the best indicator him of photosynthetic activity considering Chl- $a$, since it is a component of all plant cells, in unlike to chlorophylls $\mathrm{b}$ and $\mathrm{c}$. According values pigment index it is possible to determine the phytoplankton aging intensity and the level of reservoir pollution [25].

In our study, for the period 2017-2018 from April to September, significant differences were found in the dynamics of TSI Chl- $a$ in the Dnieper River. In particular, the minimum values of this indicator, respectively, 1,81 and $2,49 \mu \mathrm{g} / \mathrm{L}$ were recorded in the spring, when the flow river speed was increased due to the inflow of significant volumes of water as a snow melting result. The maximum values of the indicator, respectively, 64,17 and 76,34 $\mu \mathrm{g} / \mathrm{L}$, covered August, when the flow river speed and water level in the river decreased.

A similar pattern of increasing the TSI Chl- $a$ in the summer period was also found earlier in the res-
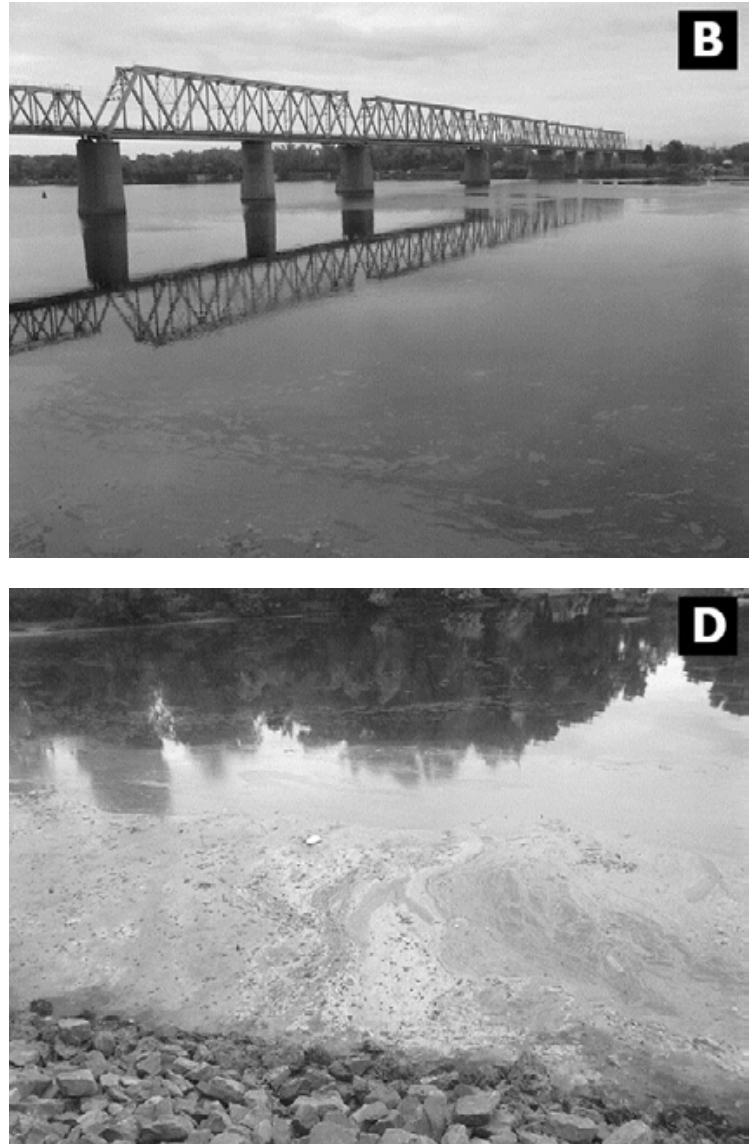

Fig. 2. View of water surface at individual points of wastewater discharge into the Dnieper River within the city of Kyiv: A, B - in August (2017) C, D - in August (2018) 
Екологічні науки № 1(24). Т. 1

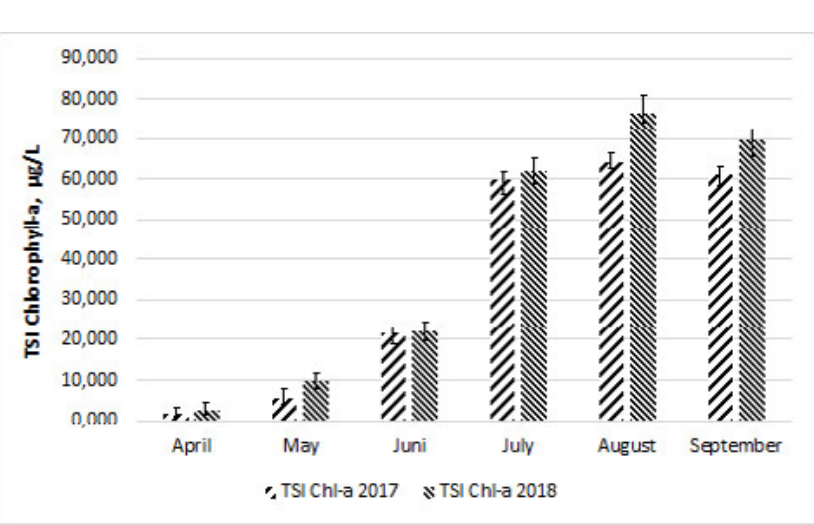

Fig. 3. The TSI Chl-a indicator dynamics in the surface layer of the Dnieper River within the city of Kiev during 2017-2018 (used "SpectroVis Plus" fluorometer, Vernier, USA)

ervoirs of the Dnieper cascade, in particular, in the work of Pichura [20] it was shown that the maximum values of this indicator occurred in August and changed within the Kyiv reservoir 1,0-15,1 $\mu \mathrm{g} / \mathrm{dm}^{3}$, Kanevsky $0,2-17,3 \mu \mathrm{g} / \mathrm{dm}^{3}$, Kremenchug 0,5-31,7 $\mu \mathrm{g} / \mathrm{dm}^{3}$, Dneprodzerzhinsky $0,5-17,5 \mu \mathrm{g} / \mathrm{dm}^{3}$, Dniprovsky $0,5-18,2 \mu \mathrm{g} / \mathrm{dm}^{3}$ and Kakhovsky $0,4-17,4 \mu \mathrm{g} / \mathrm{dm}^{3}$. Based on the available data, an increase in Chl- $a$ concentration in the summer period can be considered characteristic for the Dnieper River. In this regard, the assumption of the relationship the TSI Chl- $a$ is to the temperature and water pollution intensity may be true.

The results of our study showed that the flowering maximum intensity of the water surface in the Dnieper River within Kyiv was in August (Fig. 1). This was particularly especially manifested in the 25 -meter coastal zone, where under conditions of exposure to elevated air temperature, the water warmed up more compared to the deep-sea areas.

In particular, during the years 2017-2018, in August, TSI Chl- $a$ in shallow and stagnant water sampling sites from the Dnieper River (Fig. 2) was 1,3 and 1,6 times higher, respectively, compared to non-stagnant areas, where the temperature of the surface water layer was below. Within the sites where industrial wastewater was discharged into the Dnieper River in 2017, TSI Chl- $a$ averaged $78,47 \mu \mathrm{g} / \mathrm{L}$, and in 2018 this index reached $96,92 \mu \mathrm{g} / \mathrm{L}$, which is $26,9 \%$ higher compared to areas remote from them (Fig. 3).
A Revealed significant increase of TSI Chl-a in places of industrial wastewater discharge during 2017 (Fig. 2A, B) and 2018 (Fig. 2 C, D) in the Dnieper River, compared to places remote from them, indicates the presence of links between increasing the intensity of water pollution and the nutrients' accumulation in water.

The pigment index like TSI Chl-a, also changed, the average value of which in 2018 was $8,1 \%$ higher than the previous year.

The measuring TSI Chl- $a$ in the Dnieper within the city of Kyiv showed that the satellite images data differed slightly from indicators obtained by the fluorometer directly, as indicated by the calculated correlation coefficient of $0,87(p \leq 0,05)$.

Conclusions. Based on the results of the study, we believe, that there are no enough convincing facts, that indicate the catastrophic state of the Dnieper River, however, the tendency of increasing Chl-a concentration in water detected, within boundaries of Kyiv can in a short time may result to a significant acceleration of the river eutrophication. The integrated use of ground-based measuring instruments and satellite channels in ecological studies will help improve the monitoring accuracy the trophic status of the Dnieper River, the effectiveness of decision-making, aimed at preventing deterioration of water quality, and will also contribute solution tasks of the International Program of Global Climate Observing System in particular, of ensure methods for assessing threats to aquatic ecosystems.

Prospects of using research results. We believe, that the study results can be used to create environmental projects aimed at improving the condition of the Dnieper River, as well as to improve the accuracy of monitoring eutrophication and other natural water objects of Ukraine. The integrated use of the ArcGIS 10.4.1 computer program and the Landsat 8 satellite channel allows remotely identifying tendency and patterns in the trophic development of water bodies not only within the city of Kiev, but also in any other region of Ukraine, which is actual for hard-to-reach areas, especially which where are the fighting action. In addition, the computerized GIS tools active use in practice will contribute to the improvement of nationwide strategies for the development of environmental reforms and solving the tasks of the International climate observation program of Global Climate Observing System. 


\section{References}

1. Schindler D.W., Vallentyne J.R. The algal bowl: overfertilization of the world's freshwaters and estuaries. Edmonton, Canada : University of Alberta Press, 2008. 334 p.

2. Atmospheric carbon dioxide: its role in maintaining phytoplankton standing crops / D.W. Schindler, G.J. Brunskill, S. Emerson et al. Science. 1972. Vol. 177. № 4055. P. 1192-1194.

3. Smith V.H., Schindler D.W. Eutrophication science: where do we go from here? Trends in ecology \& evolution. 2009. Vol. 24. № 4. P. 201-207.

4. Franks P.J.S. NPZ models of plankton dynamics: their construction, coupling to physics, and application. Journal of Oceanography. 2002. Vol. 58. № 2. P. 379-387.

5. Chen Q., Mynett A.E. Integration of data mining techniques and heuristic knowledge in fuzzy logic modelling of eutrophication in Taihu Lake. Ecological Modelling. 2003. Vol. 162. № 1-2. P. 55-67.

6. Re-eutrophication of Lake Erie: correlations between tributary nutrient loads and phytoplankton biomass / D.D. Kane, J.D. Conroy, R. Peter Richards et al. Journal of Great Lakes Research. 2014. Vol. 40. № 3. P. 496-501.

7. Jorgensen S.E. Structural dynamic model. Ecological Modelling. 1986. Vol. 31. № 1-4. P. 1-9.

8. Study on mechanism experiments and evaluation methods for water eutrophication / J. Yu, Z. Wang, X. Wang et al. Journal of Chemistry. 2017. Vol. 2017. P. 1-7.

9. Мультидисциплінарний аналіз аерокосмічної і наземної інформації при оцінці стану водних екосистем на основі методів системного аналізу / О.Д. Федоровський, А.В. Хижняк, О.В. Томченко та ін. Український журнал дистанційного зондування Землі. 2015. № 7. С. 27-42.

10. A novel earth observation based ecological indicator for cyanobacterial blooms / S. Anttila, V. Fleming-Lehtinen, J. Attila et al. International Journal of Applied Earth Observation and Geoinformation. 2018. Vol. 64. June. P. 145-155.

11. Relationships among nutrients, chlorophyll-, and dissolved oxygen in agricultural streams in Illinois / A.M. Morgan, T.V. Royer, M.B. David, L.E. Gentry. Journal of Environment Quality. 2006. Vol. 35. № 4. P. 1110.

12. Satellite monitoring of cyanobacterial harmful algal bloom frequency in recreational waters and drinking water sources / J.M. Clark, B.A. Schaeffer, J.A. Darling et al. Ecological Indicators. 2017. Vol. 80. № 4. P. 84-95.

13. Kahru M., Savchuk O., Elmgren R. Satellite measurements of cyanobacterial bloom frequency in the Baltic Sea: interannual and spatial variability. Marine Ecology Progress Series. 2007. Vol. 343. P. 15-23.

14. History and timing of human impact on Lake Victoria, East Africa / D. Verschuren, T.C. Johnson, H.J. Kling et al. Proceedings of the Royal Society. B: Biological Sciences. 2002. Vol. 269. № 1488. P. 289-294.

15. Two-decade reconstruction of algal blooms in China's Lake Taihu / H. Duan, R. Ma, X. Xu et al. Environmental Science \& Technology. 2009. Vol. 43. № 10. P. 3522-3528.

16. Interannual variability of cyanobacterial blooms in Lake Erie / R.P. Stumpf, T.T. Wynne, D.B. Baker, G.L. Fahnenstiel. PLoS ONE. 2012. Vol. 7. № 8. P. 11.

17. Community composition, toxigenicity, and environmental conditions during a cyanobacterial bloom occurring along 1,100 kilometers of the Murray River / J. Al-Tebrineh, C. Merrick, D. Ryan et al. Applied and Environmental Microbiology. 2012. Vol. 78. № 1. P. 263-272.

18. Microcystins in south American aquatic ecosystems: occurrence, toxicity and toxicological assays / F.A. Dörr, E. Pinto, R.M. Soares, S.M. Feliciano de Oliveira e Azevedo. Toxicon. 2010. Vol. 56. № 7. P. 1247-1256.

19. Toxin production in cyanobacterial mats from ponds on the Mcmurdo Ice Shelf, Antarctica / B.C. Hitzfeld, C.S. Lampert, N. Spaeth et al. Toxicon. 2000. Vol. 38. № 12. P. 1731-1748.

20. Пічура В.І. Просторово-часові тенденції зміни трофічного стану водосховищ річки Дніпро. Вісник Національного університету водного господарства та природокористування. 2016. Вип. 4(76). С. 3-21.

21. Modeling chlorophyll-a and dissolved oxygen concentration in tropical floodplain lakes (Paraná River, Brazil) / R.R.A. Rocha, S.M. Thomaz, P. Carvalho et al. Brazilian Journal of Biology: Revista brasleira de biologia. 2009. Vol. 69. № 2 Suppl. P. 491-500.

22. Petteri Taalas. The global observing system for climate: implementation needs gcos-200. Ecuador, 2016. $250 \mathrm{p}$.

23. Lapyga I. Condition photosynthetic apparatus of Acer platanoides L. and Acer tataricum L. on the territory of sanitary-protective zone's "Kovalska RCS" in the city of Kyiv. Brno : Baltija Publishing, 2018. 110 p.

24. Lichman V.P., Lapyga I.V. Status of photosynthetic apparatus Prunus Armeniaca 1. at changes of lights intensity on the territories whith higest buldings in the city of Kyiv. Суми : ФОП Цьома С.П., 2018. 150 c.

25. Абакумов В.А. Руководство по методам гидробиологического анализа поверхностных вод и донных отложений. Ленинград : Гидрометеоиздат, 1983. 239 с.

26. Selecting the best band ratio to estimate chlorophyll-a concentration in a tropical freshwater lake using sentinel 2a images from a case study of Lake Ba Be (Northern Vietnam) / N.T.T. Ha, N.T.P. Thao, K. Koike et al. ISPRS International Journal of GeoInformation. 2017. Vol. 6. № 9. P. 290.

27. Water feature extraction and change detection using multitemporal landsat imagery / K. Rokni, A. Ahmad, A. Selamat, S. Hazini. Remote Sensing. 2014. Vol. 6. № 5. P. 4173-4189.

28. Herger L.G., Leinenbach P.T., Hayslip G.A. Ecological condition of lakes in Idaho, Oregon, and Washingtons. Seattle, Washington, USA : U.S. Environmental Protection Agency, Region 10, 2011. 66 p. 